\title{
Ownership concentration, foreign ownership and tunneling in Indonesia
}

\author{
Trisninik Ratih Wulandari and Doddy Setiawan
Faculty of Economic and Business, Universitas Sebelas Maret, \\ Trisninik Ratih Wulandari and Doddy Setiawan
Faculty of Economic and Business, Universitas Sebelas Maret, \\ Surakarta, Indonesia
}

\begin{abstract}
Purpose - This study aims to examine the effect of ownership concentration and foreign ownership on
Abstract
Purpose - This study aims to examine the effect of ownership concentration and foreign ownership on tunneling activities in Indonesia.

Design/methodology/approach - The population in this study were manufacturing companies listed on the Indonesian Stock Exchange from 2014 to 2018. The total observations used in this study were 557 observations. This study used three measurements to assess tunneling activities in a company, namely, related party receivables (TUL1), related party payables (TUL2) and related party receivables-payables (TUL3).

Findings - The results of this study indicated that ownership concentration and foreign ownership had a negative effect on tunneling activity of TUL1. Meanwhile, the effect of ownership concentration and foreign ownership on TUL2 and TUL3 showed a positive effect. This indicated that manufacturing companies in Indonesia preferred to carry out tunneling activities through related party payables compared with related party receivables. Foreign ownership was also effective in controlling the company's tunneling activities when the company conducted tunneling transactions of related party receivables. Small companies and companies with positive return on assets were more susceptible to tunneling activities carried out by the companies.

Practical implications - The results of this study can be used as a consideration for investors in making decisions by looking at tunneling activities carried out by companies in Indonesia.

Originality/value - To the best of the authors' knowledge, no previous study in the tunneling literature has compared the results of the effect of the concentration of foreign ownership and ownership on tunneling using three measurements at once. This is useful to see the company's behavior of tunneling activities from a different perspective.
\end{abstract}

Keywords Manufacturing companies, Tunneling, Ownership concentration, Foreign ownership, Related parties

Paper type Research paper

\section{Introduction}

Related party transactions in recent years have received a lot of attention. The Organization for Economic Cooperation and Development (OECD) states that Asian economies have to

(C) Trisninik Ratih Wulandari and Doddy Setiawan. Published in Rajagiri Management Journal. Published by Emerald Publishing Limited. This article is published under the Creative Commons Attribution (CC BY 4.0) licence. Anyone may reproduce, distribute, translate and create derivative works of this article (for both commercial and non-commercial purposes), subject to full attribution to the original publication and authors. The full terms of this licence may be seen at http://creativecommons.org/licences/by/4.0/legalcode 2021.

The authors acknowledge financial support from UNS under Grant No. 260/UN27.22/HK.07.00/ 
RAMJ

17,1

carry out comprehensive control and supervision of related party transactions. Parties are considered as related parties if one of these parties has the ability to control the other parties or has significant influence over the other parties in making financial and operational decisions. There are three main motivations for companies to conduct related party transactions. The first is economic motivation, namely, to minimize transaction costs (Fisman and Khanna, 2005). The second is the motivation to manipulate profits (Ming and Wong, 2005; Aharony et al., 2010b). The third is the motivation for tunneling purposes (Cheung et al., 2006a; Cheung et al., 2009).

Tunneling, according to Johnson et al. (2000), is a process of transferring out assets and profits from a subsidiary company for the benefit of the parent company which has an impact on the expropriation of minority shareholders by the majority shareholders. Tunneling is one of the motivations used by companies to conduct related party transactions. This is evidenced by the results of empirical research which state that related party transactions can be used by companies to get profits through tunneling activities (Aharony et al., 2010b; Cheung et al., 2006a; Gao and Kling, 2008; Ming and Wong, 2005; Juliarto et al., 2013; Hamid et al., 2016).

Ming and Wong (2005) and Cheung et al. (2006b) have found that companies can perform tunneling in various ways, such as related party receivables, through asset transactions, trade transactions, cash payments and equity transactions to related parties. A kind of tunneling practice that is often carried out by companies is by providing receivables in large amounts or long credit terms to related parties. Receivables granted to a related party can be treated as a sell option, that is, the related party uses this option by not paying the receivables when the company is in bad condition (Atanasov et al., 2014). Giving and writing off related party loans will have an impact on the decrease in net income of the tunneled company.

Tunneling through related party transactions is suspected to be the cause of the 1997 Asian crisis. The case of tunneling in Indonesia that had been indicated or proven to harm non-controlling shareholders occurred in PT Sumalindo Lestari Jaya Tbk (SULI). It was found that there were transactions that contained conflicts of interest and lack of transparency in various company activities. The board of directors and majority shareholders were suspected of having participated in the affiliated transactions which resulted in minority shareholders' losses. Several PT SULI transactions were considered detrimental to minority shareholders, the first is an inbreng transaction of Industrial Plantation Forest assets, or disposal of assets by SULI to its subsidiary, PT Sumalindo Alam Lestari, with transaction value that is not fair. Information on these transactions was never disclosed on General Meeting of Shareholders and Extraordinary General Meeting of Shareholders to minority shareholders. Second, the purchase of bonds without coupons issued by PT. Sumalindo Hutani Jaya (subsidiary), without debt collateral. Both transactions can occurs because there is a controlling shareholder who serves as the board of directors commissioners or company directors. In addition, all shareholders PT SULI has a family relationship that has the potential to create a conflict of interest. Fact there is a family relationship between the board of directors and the controlling shareholder of PT. SULI greatly influences all company-oriented policies benefit the majority shareholder and detrimental to the interests of minority shareholders or the public.

Family and concentrated ownership structures in companies in Indonesia are one of the causes of tunneling. The characteristic of a concentrated ownership structure is if in a company there are one or more shareholders owning 20\% of the shares (Bapepam No IX. H.1). In Figure 1, it can be seen that the average level of share ownership concentration in manufacturing companies in Indonesia is above $50 \%$. Protection for minority shareholders 
already exists in Indonesia, namely, Bapepam Regulation No. 1X.E.1, which explains the protection of the rights of minority shareholders as well as PSAK No. 7 of 2018 which contains the company's obligations to disclose related party transactions. However, there are still companies that have not implemented these regulations. This is because of the lack of law enforcement in Indonesia, resulting in tunneling practices that harm minority shareholders.

The research showing that manufacturing companies in Indonesia apply concentrated ownership structure is Claessens et al. (2000), who state that $66.9 \%$ of the 178 samples of public companies in Indonesia have a concentrated ownership structure through a pyramid form with family as the main controller. Zhuang et al. (2001) show that the ownership structure in Indonesia is concentrated in the five largest owners, which is about $67.5 \%$. This result is supported by Gunarsih (2017), which states that, on average, $65 \%$ of concentrated ownership is in three large owners and is owned by institutions. The ownership structure in Indonesia is classified as a concentrated ownership structure.

Agency conflicts that arise because of the presence of a concentrated ownership structure are conflicts between majority shareholders and minority shareholders, which, in agency theory, is agency problem Type 2 (Shleifer and Vishny, 1997; Zhuang et al., 2001). This is in accordance with the statement of Shleifer and Vishny (1997) that if the concentrated ownership has crossed a certain limit, the majority shareholder can fully control the company and they tend to make policies that can only benefit themselves. The agency conflicts that occur are strongly influenced by the high concentration of company ownership. In highly concentrated ownership structures, agency conflict is higher than in low concentrated ownership structures (Gugler et al., 2003; Dewenter and Warther, 1998).

The results of the study on the effect of ownership structure on tunneling activity in the form of related party loans that is done by the company still varies. (Jiang et al., 2010; Liu and Lu, 2007; Luo and Jackson, 2012a, 2012b; Guo et al., 2019), stated that there was an influence ownership structure for tunneling activities in the form of related party loans. (Holmen and Högfeldt, 2011; Juliarto et al., 2013; Vegt et al., 2012) show different results, namely there is no effect ownership structure for tunneling activities in the form of related party loans made by the company.

One of the aspects that can reduce the agency problem Type 2 is the presence of foreign ownership. Foreign ownership in several studies can be an effective mechanism to monitor the management from activities that can reduce the company value (David, 1996; M.W. Peng, 2003; Tihanyi et al., 2003; Zhang et al., 2017). Foreign investors can have the

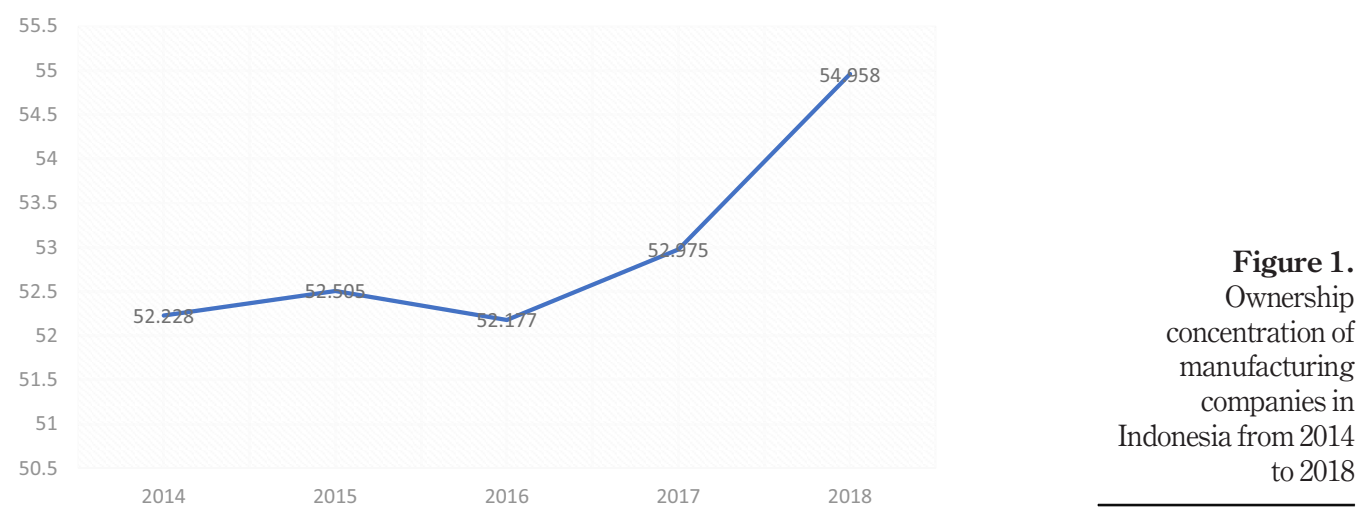


RAMJ

17,1

\section{4}

ability to reduce the company's dependence on concentrated ownership (Sari et al., 2016). However, several studies state that foreign ownership can also carry out tunneling activities (Dyreng and Lindsey, 2011; Graham et al., 2011).

The average foreign ownership in manufacturing companies in Indonesia from 2014 to 2018 can be seen in Figure 2, which is above $20 \%$. The average foreign ownership in Indonesia during the 5 years was $27.39 \%$. This shows that the number of foreign ownership in Indonesia is quite high, especially in 2014 , reaching an average of $39.71 \%$.

The results of research related to the effect of foreign ownership on tunneling activities are still varied. Several studies stated that foreign ownership can reduce the opportunistic behavior of the majority shareholders (David, 1996; Peng, 2003; Tihanyi et al., 2003; Zhang et al., 2017). Meanwhile, other studies state that when investors have great control, they will tend to carry out activities that benefit them, one of which is tunneling (Dyreng and Lindsey, 2011; Graham et al., 2011).

This study used three measurements to see the tunneling activity of related party loans in Indonesia that have not been carried out by previous researchers. The purpose of using these three measurements was to provide a more detailed picture to other researchers and investors regarding the tunneling activity of related party loans which was often carried out by manufacturing companies in Indonesia that have a concentrated ownership structure. The three transactions used as the basis for tunneling measurement in this study were related party payables, related party receivables and related party payables-receivables.

\section{Background, literature and hypothesis development}

\subsection{Ownership concentration and tunneling}

The agency problem is one of the central issues in financial research these days. The emergence of agency problems is strongly influenced by the high and low concentration of company ownership. Companies with highly concentrated ownership structures will have higher agency conflicts compared to companies with low ownership structures (Dewenter and Warther, 1998; Gugler et al., 2003). Companies with high ownership concentration cause the majority shareholder to control management and even become part of it management itself. The majority shareholders can expropriate the minority shareholders. There are two activities by which the majority shareholders can take benefit from the control of the policy he/she has, first through the company's operational policy, including the provision of high salaries and allowances, bonuses and large compensation to the majority shareholders. The second way is through contractual policies with other parties, including through tunneling (Gilson and Gordon, 2005).

\section{Figure 2.}

Average percentage of foreign ownership of manufacturing companies in Indonesia from 2014 to 2018

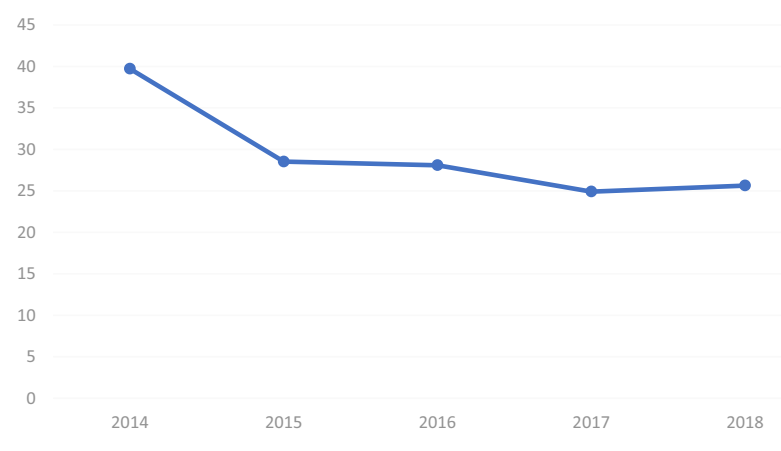


The ownership structure in ASEAN countries, including Indonesia, according to Claessens et al. (2000), shows a concentrated ownership structure. This ownership structure leads to the formation of majority shareholders and minority shareholders. The existence of the majority shareholders causes the agency conflict Type 2, namely, the tendency for the majority shareholders to have more authority and information to transfer the company's assets for personal gain regardless of the rights of minority shareholders (Marfuah and Azizah, 2014). PSAK No. 15 states that a party can be said to be the majority shareholder if it owns shares or securities of $20 \%$ or more. The majority shareholders usually also own majority shares in other related companies. This situation causes tunneling practices which provide benefits for the majority shareholders (Susanti and Firmansyah, 2020). Weak legal protection for minority shareholders is also one of the reasons for the majority shareholders to perform tunneling. In addition, companies in Indonesia have a low level of compliance with mandatory disclosures made by issuers on the Indonesia Stock Exchange (IDX; Hapsoro, 2008). Disclosure made for related party transactions is still minimal, so companies often do not clearly show related party transactions that can damage the companies' value, such as tunneling.

Cheung et al. (2006b), Cheung et al. (2009) and Ming and Wong (2005) have found that there are many ways for companies to perform tunneling, namely, through loan transactions, asset transactions, trade transactions, cash payments and equity transactions to related parties. The tunneling activity of related party loans is carried out by companies by providing large amounts of receivables or long credit terms to related parties. Receivables granted to a related party can be treated as a sell option in which the related party can carry out this option by not paying the receivables in a bad situation (Atanasov et al., 2014). The activities of providing and writing off related party loans will have an impact on the decrease in the company's net income.

The research related to tunneling through related party receivables transactions conducted by Aharony et al. (2010a), Ming and Wong (2005), Li et al. (2009) and Sari et al. (2016) have found companies that issue loan guarantees to related parties have a purpose to take over the wealth of minority shareholders. Cheung et al. (2009) also find empirical evidence of companies using receivable and loan transactions arising from sales and purchase transactions with related parties for the profit of majority shareholders.

The results of research related to the effect of ownership structure on related party loan tunneling show that there is an influence between concentrated ownership structure and related loan tunneling activities in several countries in Asia (Li et al., 2010; Luo and Jackson, 2012a, 2012b; Guo et al., 2019). Several studies conducted by Jiang et al. (2010), Chen et al. (2017) and Chizema et al. (2020) have found that with the increasing concentration of share ownership, the level of related party loans also increases. Based on the explanation above, the first hypothesis in this study is as follows:

H1. Concentrated ownership structure has a positive effect on related party loan tunneling.

\subsection{Foreign ownership}

Dahlquist and Robertsson (2001) find that foreign ownership can be seen as an effective mechanism, besides corporate governance, that can be used to supervise and monitor company activities. Foreign investors are considered to have better supervisory capabilities so that they can help companies stay away from excessive dependence on concentrated ownership (Claessens et al., 2000; Zhang et al., 2017; Sari and Baridwan, 2014).
Tunneling in
Indonesia 
RAMJ

17,1

26

King and Schroeder (2013) also find that the presence of foreign investors in developing countries would encourage better governance. The presence of foreign investors also encourages transparency and pressures the government to increase the protection of minority shareholders (Peng, 2003). The demand for transparency implies a reduction in information asymmetry and consequently prevents opportunistic behavior. Likewise, increased government protection of minority shareholders creates pressure for companies to take actions that do not harm minority shareholders. This study hopes that the higher the foreign ownership, the higher it can increase the company's supervisory function on opportunistic behavior, including tunneling.

The average level of foreign ownership in Indonesia is high, namely, 27.39\% from 2014 to 2018. A high percentage of foreign ownership can improve corporate governance. In addition, it will also reduce the opportunistic behavior of the majority shareholders. Based on the explanation above, the second hypothesis that we make is as follows:

H2. Foreign ownership has a negative effect on related loans tunneling.

\section{Research methodology}

\subsection{Sampling and data sources}

The samples we used in this study were all manufacturing companies listed in the IDX from 2014 to 2018. We chose manufacturing companies because several cases of tunneling in Indonesia occurred in manufacturing companies (PT SULI, PT INAI and PT CPIN). In addition, manufacturing companies also dominated the IDX, namely, as many as 167 companies out of 613 companies listed on the IDX in 2018 (27\%). The final sample selection was carried out by excluding companies that did not have complete data during the research period.

The results of purposive sampling for all manufacturing companies listed on the IDX for 5 years were 557 observations. The observations for the large companies were 277 and small companies were 280 observations. Meanwhile, the companies that experienced profits during the study period were 450 observations and those that experienced losses were 107 observations (Table 1).

\subsection{Dependent variable}

The dependent variable in this study was TUL (tunneling) which was measured using three measurements, namely, related party total receivables/total assets, related party total payables/total assets and related party total payables - total receivables/total assets. The previous research (Jiang and Lee, 2009; Liu and Lu, 2007; Aharony et al., 2010a) measures tunneling using related party receivables and other payables divided by total assets. This

Sample selection process

Total companies listed on IDX from 2014 to 2018

Minus

The company did not have complete data during the research period

The final sample was used

Small company

Large company

Profit company

Loss company
No. of companies 576 
study measures tunneling using total related party receivables and related party accounts payable not only using other related party receivables and other related party accounts payable. This was done to fully describe the misappropriations committed by the majority shareholder.

Tang (2016) also uses total related party receivables divided by total assets to measure tunneling. This research was different with the research conducted by Tang (2016). This research used three measurements, namely, total receivables, total payables and total related party receivables divided by total assets. The reason for using all three measurements in this study was to provide a complete picture of how tunneling activities were carried out by manufacturing companies in Indonesia.

\subsection{Independent variable}

There were two independent variables used in this study, namely, the ownership concentration (KONS) and foreign ownership (FOREIGN). The KONS was the highest percentage of share ownership owned by shareholders in manufacturing companies listed on the IDX from 2014 to 2018. Meanwhile, FOREIGN was the percentage of shares owned by foreign investors who invested shares in the manufacturing company in Indonesia.

\subsection{Control variable}

This study used five control variables, namely, leverage (LEV) which was proxied by debt to asset, which was measured by dividing total payables by total assets multiplied by $100 \%$. The second control variable was return on assets (ROA), which was calculated by dividing total profit before tax by total assets. SIZE was the natural logarithm of total assets, then GROWTH was calculated by dividing the stock market price by the share book value. The last control variable was audit size (AS), which was measured using a dummy variable, provided that the score was 1 if the company was audited by big four KAP and 0 if it was audited by a non-big four KAP.

\subsection{Research design}

We build the model below to achieve our research objectives. This model is to prove the effect of concentration ownership and foreign ownership on tunneling activities of manufacturing companies in Indonesia. We used multiple linear regression analysis techniques with panel data to test this effect. The following is the model we used in this study to test $H 1$ and $H 2$ :

$$
\begin{aligned}
\mathrm{TUL}= & \beta_{0}+\beta_{1} \mathrm{KONS}+\beta_{2} \mathrm{FOREIGN}+\beta_{3} \mathrm{LEV}+\beta 4 \mathrm{ROA}+\beta 5 \mathrm{SIZE}+\beta 6 \mathrm{GROWTH} \\
& +\beta 7 \mathrm{AS}+\mathrm{e}
\end{aligned}
$$

where:

TUL = related party tunneling calculated using three measurements:

TUL 1 = related party receivables/total asset;

TUL 2 = related party payables/total asset; and

TUL $3=$ related party payables-receivables/total asset.

KONS = ownership concentration is the highest percentage of share ownership owned by shareholders;

FOREIGN $=$ foreign ownership is the percentage of the total shares owned by foreign investors;

Tunneling in Indonesia 


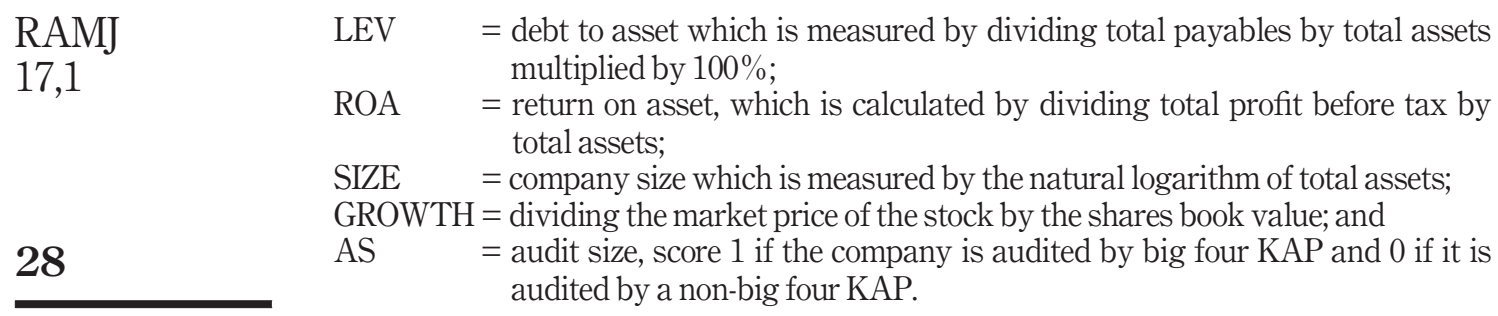

This study also distinguished large and small companies. The company size classification used the proxy size. This was done to see whether there was a difference in the effect of ownership concentration and foreign ownership on tunneling activities carried out by large companies and small companies. Besides, this study also distinguished companies that experienced profits and those that experienced losses. The differentiation of this company was done by looking at ROA; positive ROA meant that the company was in a profit and negative ROA meant that the company was in a loss. The purpose of differentiating this sample was to see if there were differences in the tunneling activities carried out by those two types company.

\section{Research results}

\subsection{Descriptive statistics result}

Based on the results of descriptive statistics in Table 2, the average TUL1 value for all manufacturing companies listed on the IDX during the period 2014-2018 is 0.042. The average value of TUL1 for large companies is 0.038 , whereas for small companies, it is 0.047 . These results show that the large companies have lower TUL1 than small companies. This means that large companies tend to use related party loans in the form of related party receivables, which are smaller than small companies. The average TUL1 results for companies that have positive ROA (0.043) is greater than companies that have negative ROA (0.041). This means that companies that have positive ROA use related receivables more than companies that have negative ROA.

The average of total TUL2 is 0.038 , meaning that the ratio between related party payables to total assets is $3.8 \%$. Large companies have a smaller TUL2 value compared with small companies. This result is the same as TUL1. However, the average TUL2 is

\begin{tabular}{lccccc}
\hline Variables & Large size & Small size & Positive ROA & Negative ROA & Total \\
\hline TUL1 & 0.037686 & 0.047054 & 0.042642 & 0.041268 & 0.042378 \\
TUL2 & 0.033856 & 0.042822 & 0.030156 & 0.072798 & 0.038347 \\
TUL3 & -0.003830 & -0.004231 & -0.012487 & 0.031530 & -0.004031 \\
KONS & 54.74406 & 52.36516 & 52.96249 & 56.03374 & 53.55248 \\
FOREIGN & 33.24004 & 21.56753 & 28.29813 & 23.58794 & 27.39330 \\
DAR & 45.96664 & 47.03545 & 44.35066 & 55.54969 & 46.50200 \\
ROA & 6.587587 & 3.066499 & - & & \\
SIZE & - & - & 14.83551 & 14.20702 & 14.71478 \\
GROWTH & 4.381517 & 2.485877 & 3.122180 & 4.734955 & 3.431995 \\
AS & 0.604317 & 0.268817 & 0.440000 & 0.476636 & 0.436266 \\
Observation & 278 & 279 & 450 & 107 & 557
\end{tabular}

Table 2.

Descriptive statistics
Notes: TUL1:related party receivables/TA; TUL2: related party payables/TA; TUL3: related party payables-receivables/TA; KONS: ownership concentration; FOREIGN: percentage of foreign ownership; ROA: return on asset; SIZE: LnTA; GROWTH: market to book value 
different from TUL1, in which companies that have negative ROA (0.072) are greater than companies that have positive ROA (0.030), and the difference is quite large. This shows that companies that have negative ROA have more related payables than companies that have positive ROA.

Total TUL3 shows that the results of manufacturing companies in Indonesia from 2014 to 2018 have more related party receivables compared with related party payables. The same results are also for large companies, small companies and companies with positive ROA, they have more related party receivables than related party payable. This result supports the descriptive statistics result for TUL1 and TUL2.

The results of descriptive statistics in Table 2 show the level of ownership concentration manufacturing companies in Indonesia during 2014-2018 showed 53.55\%, more than $20 \%$, this means that manufacturing companies in Indonesia are included in the concentrated type of company. Large size companies have greater ownership concentration compared with small size companies, similar to the level of foreign ownership (FOREIGN). Meanwhile, for companies that have negative ROA, the level of ownership concentration is greater than companies that have positive ROA. This result is inversely proportional to the average percentage of foreign ownership; that is, companies with a positive ROA are greater than those with negative ROA.

\subsection{Hypothesis testing results}

The results of $H 1$ and $H 2$ testings can be seen in Table 3. Based on Table 3, TUL1 shows the regression coefficient of -2.446 , with a significance level of 0.014 , less than $5 \%$. This shows that KONS has a negative effect on TUL1. Therefore, H1, which states that KONS has a positive effect on TUL1, is not supported. This study shows that the higher the level of company ownership concentration, the lower the companies conduct tunneling in the form of related party receivables, and vice versa. This occurs because high receivables from related parties will reduce the companies' value (Cheung et al., 2006b; Cheung et al., 2009; Sari and Baridwan, 2014) so that companies with a high level of ownership concentration prefer to increase the companies' value than undertake tunneling activities to gain benefit from minority shareholders.

The results for TUL2 are different from TUL1. In Table 3, it can be seen that TUL2 shows a coefficient of 1.917 with a significance level of 0.0558 , below $10 \%$. These results indicate that KONS has a positive influence on loans tunneling in the form of related party

\begin{tabular}{|c|c|c|c|c|c|c|c|c|}
\hline \multirow[b]{2}{*}{ Variables } & \multirow[b]{2}{*}{ Hypothesis } & \multicolumn{2}{|c|}{ TUL1 } & \multicolumn{2}{|c|}{ TUL2 } & \multicolumn{2}{|c|}{ TUL3 } & \\
\hline & & t-stat & Prob & t-stat & Prob & t-stat & Prob & \\
\hline $\mathrm{C}$ & & 1.553138 & 0.1210 & 3.141438 & 0.0018 & -0.827245 & 0.4085 & \\
\hline KONS & Positive & -2.446075 & 0.0148 & 1.916854 & 0.0558 & 3.862668 & 0.0001 & \\
\hline FOREIGN & Negative & -2.196228 & 0.0285 & 1.874032 & 0.0615 & 4.412092 & 0.0000 & \\
\hline DAR & & 0.467809 & 0.6401 & 12.82724 & 0.0000 & 2.584724 & 0.0100 & \\
\hline ROA & & 1.818031 & 0.0696 & -0.363047 & 0.7167 & -1.666951 & 0.0961 & Table 3. \\
\hline SIZE & & -0.062332 & 0.9503 & -5.724110 & 0.0000 & -2.514340 & 0.0122 & Hynothesis testing \\
\hline GROWTH & & -2.957675 & 0.0032 & -3.754423 & 0.0002 & -2.843264 & 0.0046 & Hypothesis testin \\
\hline AS & & 1.930728 & 0.0540 & 1.202507 & 0.2297 & -1.243208 & 0.2143 & results for \\
\hline$R$-squared & & \multicolumn{2}{|c|}{0.034455} & \multicolumn{2}{|c|}{0.106972} & \multicolumn{2}{|c|}{0.066420} & manufacturing \\
\hline $\operatorname{Adj} R$-squared & & \multicolumn{2}{|c|}{0.022144} & \multicolumn{2}{|c|}{0.095585} & \multicolumn{2}{|c|}{0.054517} & companies in \\
\hline$F$ Statistics & & \multicolumn{2}{|c|}{2.798674} & \multicolumn{2}{|c|}{9.394585} & \multicolumn{2}{|c|}{5.579846} & Indonesia from 2014 \\
\hline Probability ( $F$ Stat) & & \multicolumn{2}{|c|}{0,007196} & \multicolumn{2}{|c|}{0.000000} & \multicolumn{2}{|c|}{0.000003} & to 2018 \\
\hline
\end{tabular}

Tunneling in Indonesia 
RAMJ

17,1

payables ( $H 1$ is supported). This means that the higher the level of ownership concentration of share in a company, the tunneling activity in the form of related party payables will increase. The increase in related party payables could be because of the high level of purchases from related parties. Companies with a high level of ownership concentration choose to make purchase transactions above market prices with related parties, namely, subsidiaries. The objective is to reduce the parent company's net profit and increase the subsidiary's net profit. If the parent company's net profit is low, the amount of dividends paid to shareholders will decrease. This will be detrimental to minority shareholders. Meanwhile, the majority shareholder of the parent company does not experience a loss because they are also the majority shareholder in the subsidiary whose net profit has increased. The research result conducted by Claessens et al. (2000) states that the majority shareholder of the parent companies in Indonesia is also the majority shareholder of the subsidiary companies. Tunneling activities also occur in Indonesia because of the lack of strict law enforcement in implementing the established rules (Bapepam Regulation No. 1X. E.1 and PSAK No. 7 of 2018). The results of this study support previous research conducted by Jiang and Lee (2009), Jiang et al. (2010), Chen et al. (2017) and Chizema et al. (2020).

The first hypothesis using TUL3 (payables-receivables) shows the same results as TUL2. These results can be seen in Table 3 , namely, the regression coefficient of the effect of KONS on TUL3 of 3.862668 with a significance level of 0.0001 , below 0.05 . This means that there is a positive effect between ownership concentration and TUL3 (H1 is supported). Seeing the results of the descriptive statistics in Table 2, the total TUL3 is negative, meaning that the level of related party receivables is higher than related party payables. However, the number of companies that perform tunneling through related party receivables (negative TUL3) was smaller than companies that perform tunneling through related party payables (TUL3 positive), namely, $226(40 \%)$ and $331(60 \%)$. The number of companies that perform tunneling through related party payables was more than those that perform tunneling through related party receivables. Therefore, the results of TUL3 are the same as TUL2 compared with TUL1. The results of this study support the results of research conducted by previous researchers that there is a positive effect between ownership concentration and TUL3 (Friedman et al., 2003; Atanasov et al., 2014; Guo et al., 2019).

The results of $H 2$ of the effect of FOREIGN and Tunneling can also be seen in Table 3. First, the effect of Foreign on TUL1 shows that there is a negative effect between FOREIGN and TUL1 (related party receivables), evidenced by the regression coefficient of -2.196228 with a significance level of 0.0285 , meaning that $H 1$ is supported. This negative effect shows that the higher the percentage of foreign ownership, the lower the tunneling level through related party receivables. This means that foreign ownership in Indonesia can control the tunneling of related party receivables. Foreign investors are parties considered capable to control the behavior of majority shareholders which might harm minority shareholders, especially through related party loan transactions.

King and Schroeder (2013) argue about the importance of the role of foreign ownership in institutional reform. Foreign investors are parties that are outside the domestic social network; therefore, they tend to encourage transparent agreements and give pressure on the government to increase the protection of minority shareholders (Peng, 2003). Foreign shareholders are considered to be more resistant to pressure from problems generated by domestic government policies (Kochhar and David, 1996; Tihanyi et al., 2003). This is also supported by the results of the first hypothesis which states that concentrated ownership has a negative effect on tunneling. This means that the majority shareholders in Indonesia have decreased tunneling activities because of interference from foreign ownership in Indonesia. 
The results of the effect of FOREIGN on TUL1 are different from those of FOREIGN with TUL2 and TUL3. The results using TUL2 and TUL3 show that there is a positive effect (regression coefficient 1.1916 with a significance level of 0.05558 ), meaning that the hypothesis is not supported. The higher the level of foreign ownership in the company, the higher the tunneling carried out by the company in the form of related party payables. Likewise, for TUL3, FOREIGN has a positive effect on TUL3. This means that for TUL2 and TUL3, the level of foreign ownership cannot reduce the tunneling action taken by the company. This is also supported by the results of $H 1$, which state that concentrated ownership has a negative effect on tunneling, meaning that when a company is tunneling through related party payables, the role of foreign ownership to reduce tunneling is not effective. The results of this study are supported by Agarwal et al. (2009) and Juliarto et al. (2013).

This research divided the companies into two categories, namely, large companies and small companies. The results in Table 4 and 5 show that in large companies, ownership concentration (KONS) has no effect on TUL1, TUL2 and TUL3. This result is different from small companies, in which KONS has an effect on TUL1, TUL2 and TUL 3. This shows that small size companies are more susceptible to tunneling activity compared with large companies. Large companies have more control over tunneling activities carried out by the majority shareholders. Foreign ownership is one of the parties considered capable of playing

\begin{tabular}{lcccccc}
\hline & \multicolumn{2}{c}{ TUL1 } & \multicolumn{2}{c}{ TUL2 } & \multicolumn{2}{c}{ TUL3 } \\
Variables & t-stat & Prob & t-stat & Prob & t-stat & Prob \\
\hline C & 4.671728 & 0.0000 & -1.837860 & 0.0672 & -3.465120 & 0.0006 \\
KONS & -0.676341 & 0.4994 & 0.256831 & 0.7975 & 0.622999 & 0.5338 \\
FOREIGN & -3.771728 & 0.0002 & 1.254335 & 0.2108 & 4.188685 & 0.0000 \\
DAR & 1.650765 & 0.0999 & 9.951638 & 0.0000 & 13.98211 & 0.0000 \\
ROA & 0.020663 & 0.9835 & 0.655078 & 0.5130 & 1.451052 & 0.1479 \\
GROWTH & -1.592018 & 0.1125 & -1.382925 & 0.1678 & -1.080242 & 0.2810 \\
AS & 3.693686 & 0.0003 & 1.286689 & 0.1993 & -2.873223 & 0.0044 \\
$R$-squared & 0.046474 & 0.082498 & & 0.064431 & 0.043717 \\
Adj $R$-squared & 0.025362 & 0.062184 & 3.110529 \\
$F$-statistics & 2.201371 & 4.061201 & 0.005796 \\
Probability $(F$-stat) & 0.043179 & 0.000644 &
\end{tabular}

Tunneling in Indonesia

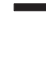


RAMJ

17,1

\section{2}

Table 6.

Hypothesis testing results: positive ROA

a role in controlling tunneling actions carried out by the majority shareholder. The results in tables 4 and 5 almost all show that there is an effect of foreign ownership (FOREIGN) on all tunneling activities in large and small companies, except for TUL2 in large companies, The results show that foreign ownership (FOREIGN) has no effect on tunneling activity (TUL2).

This research also divides companies into two categories, namely, the companies that have positive ROA and negative ROA. The results in Table 6 and 7 show that in positive ROA, KONS has no effect on TUL1, but KONS has a positive effect on TUL2 and TUL3. Meanwhile, FOREIGN has a negative effect on TUL1 but has a positive effect on TUL3 and no effect on TUL2. In companies with negative ROA (Table 6), there is no effect of KONS on TUL1, TUL2 or TUL3. Likewise, for H2, FOREIGN has no effect on TUL1, TUL2 and TUL3. These results indicate companies with positive ROA are more susceptible to carry out tunneling activities. A company with a positive ROA performs tunneling in the form of related party payables and foreign ownership cannot reduce the company's tunneling activities.

\section{Conclusion}

This study examines the effects of KONS and FOREIGN on tunneling activities carried out by manufacturing companies in Indonesia. The companies used as research samples

\begin{tabular}{|c|c|c|c|c|c|c|}
\hline \multirow[b]{2}{*}{ Variables } & \multicolumn{2}{|c|}{ TUL1 } & \multicolumn{2}{|c|}{ TUL2 } & \multicolumn{2}{|c|}{ TUL3 } \\
\hline & t-stat & Prob & t-stat & Prob & t-stat & Prob \\
\hline $\mathrm{C}$ & 3.598832 & 0.0004 & 6.749154 & 0.0000 & -1.749524 & 0.0809 \\
\hline KONS & -1.554254 & 0.1208 & 2.046673 & 0.0413 & 1.940364 & 0.0530 \\
\hline FOREIGN & -1.724368 & 0.0853 & 1.142148 & 0.2540 & 2.458650 & 0.0143 \\
\hline DAR & -0.165467 & 0.8687 & 6.564765 & 0.0000 & 3.556823 & 0.0004 \\
\hline SIZE & -3.062087 & 0.0023 & -6.945549 & 0.0000 & 0.719641 & 0.4721 \\
\hline GROWTH & 0.136873 & 0.8912 & -1.656931 & 0.0982 & -1.421869 & 0.1558 \\
\hline AS & 8.430457 & 0.0000 & 3.119942 & 0.0019 & -1.705970 & 0.0887 \\
\hline$R$-squared & \multicolumn{2}{|c|}{0.058839} & \multicolumn{2}{|c|}{0.073802} & \multicolumn{2}{|c|}{0.052822} \\
\hline $\operatorname{Adj} R$-squared & \multicolumn{2}{|c|}{0.046092} & \multicolumn{2}{|c|}{0.061258} & \multicolumn{2}{|c|}{0.039993} \\
\hline$F$-statistics & \multirow{2}{*}{\multicolumn{2}{|c|}{4.615873}} & \multirow{2}{*}{\multicolumn{2}{|c|}{$\begin{array}{l}5.883242 \\
0.000006\end{array}$}} & \multirow{2}{*}{\multicolumn{2}{|c|}{$\begin{array}{l}4.117502 \\
0.000490\end{array}$}} \\
\hline Probability ( $F$-stat) & & & & & & \\
\hline
\end{tabular}

Table 7.

Hypothesis testing results: negative $\mathrm{ROA}$

\begin{tabular}{lcccrrr}
\hline & \multicolumn{2}{c}{ TUL1 } & \multicolumn{2}{c}{ TUL2 } & \multicolumn{2}{c}{ TUL3 } \\
Variables & t-stat & Prob & t-stat & Prob & t-stat & Prob \\
\hline C & -0.278874 & 0.7809 & 0.289009 & 0.7732 & -1.092343 & 0.2773 \\
KONS & 0.931769 & 0.3537 & 1.273806 & 0.2057 & 1.198174 & 0.2337 \\
FOREIGN & -1.524017 & 0.1307 & 1.630390 & 0.1062 & 1.623337 & 0.1077 \\
DAR & -0.724477 & 0.4705 & 6.062412 & 0.0000 & 5.855444 & 0.0000 \\
SIZE & 1.813090 & 0.0728 & -1.732590 & 0.0863 & -1.032532 & 0.3043 \\
GROWTH & -5.085657 & 0.0000 & -3.724835 & 0.0003 & -2.509807 & 0.0137 \\
AS & 0.478375 & 0.6334 & 0.737263 & 0.4627 & 0.350411 & 0.7268 \\
$R$-squared & 0.174879 & 0.184564 & 0.190574 & \\
Adj $R$-squared & 0.129971 & 0.135638 & 0.142008 & \\
$F$-statistics & 3.545852 & 3.772302 & 3.924050 & \\
Probability $(F$-stat) & 0.002110 & 0.001991 & 0.001457 & \\
\hline
\end{tabular}


were manufacturing companies listed on the IDX from 2014 to 2018. Tunneling used three measurements, namely, related party receivables, related party payables and net related party loans (payables-receivables). This study also divided the samples into large companies and small companies, as well as companies with positive ROA and negative ROA.

The results of the research for the samples of all manufacturing companies were that KONS had a negative effect on TUL1 but had a positive effect on TUL2 and TUL3. FOREIGN has a negative effect on TUL1 but has a positive effect on TUL2 and TU3. These results indicate companies with a high level of ownership concentration prefer not to perform related party receivables tunneling because this tunneling activity will decrease the companies' value. This is also suspected because of the interference of foreign shareholders so that tunneling activities of related parties can be controlled. The results for TUL2 are different because of tunneling activity in the form of related party payables. This happens because the majority shareholder will benefit from the higher related party debt. Weak law enforcement in Indonesia is also one of the causes of tunneling activity. Foreign ownership also supports the company's actions to conduct tunneling because it can increase the profits of the majority shareholder. The results of the effect of KONS and FOREIGN on TUL3 show the same results as in TUL2. When tunneling activities use net related party loans (receivables-payables), KONS and FOREIGN have a positive effect on tunneling activities carried out by the companies.

The results of dividing the samples into large companies and small companies show that small companies are more susceptible to tunneling actions carried out by companies compared with large companies. Likewise, for companies with positive ROA, these companies are also more susceptible to tunneling action than companies with negative ROA.

The findings of our study have several practical implications. First, regulators must be more assertive in enforcing the rules that have been set so that they will further minimize activities that can harm minority shareholders. Second, this study can provide a more detailed explanation to investors regarding the tunneling activity of related party loans that is often carried out by companies in Indonesia so that investors can make the right investment decisions.

\section{References}

Agarwal, S., Faircloth, S., Liu, C. and Ghon Rhee, S. (2009), "Why do foreign investors underperform domestic investors in trading activities? Evidence from Indonesia", Journal of Financial Markets, Vol. 12 No. 1, pp. 32-53, doi: 10.1016/j.finmar.2008.04.001.

Aharony, J., Barniv, R. and Falk, H. (2010a), "The impact of mandatory IFRS adoption on equity valuation of accounting numbers for security investors in the EU", European Accounting Review, Vol. 19 No. 3, pp. 535-578, doi: 10.1080/09638180.2010.506285.

Aharony, J., Wang, J. and Yuan, H. (2010b), "Tunneling as an incentive for earnings management during the IPO process in China", Journal of Accounting and Public Policy, Vol. 29 No. 1, pp. 1-26, doi: 10.1016/j.jaccpubpol.2009.10.003.

Atanasov, V., Black, B. and Ciccotello, C.S. (2014), "Unbundling and measuring tunneling”, University of Illinois Law Review, Vol. 5, pp. 1697-1738, doi: 10.2139/ssrn.1030529.

Chen, W., Li, S. and Chen, C.X. (2017), "How much control causes tunneling? Evidence from China", China Journal of Accounting Research, Vol. 10 No. 3, pp. 231-245, doi: 10.1016/j.cjar.2016.10.001.

Cheung, Y.W., Chinn, M.D. and Fujii, E. (2006a), "The Chinese economies in global context: the integration process and its determinants", Journal of the Japanese and International Economies, Vol. 20 No. 1, pp. 128-153, doi: 10.1016/j.jjie.2004.12.001.

Tunneling in Indonesia

\section{$=$}


RAMJ

17,1

Cheung, Y.L., Rau, P.R. and Stouraitis, A. (2006b), “Tunneling, propping, and expropriation: evidence from connected party transactions in Hong Kong”, Journal of Financial Economics, Vol. 82 No. 2, pp. 343-386, doi: 10.1016/j.jfineco.2004.08.012.

Cheung, Y.L., Jing, L., Lu, T., Rau, P.R. and Stouraitis, A. (2009), “Tunneling and propping up: an analysis of related party transactions by Chinese listed companies", Pacific-Basin Finance Journal, Vol. 17 No. 3, pp. 372-393, doi: 10.1016/j.pacfin.2008.10.001.

Chizema, A., Jiang, W., Kuo, J.M. and Song, X. (2020), "Mutual funds, tunneling and firm performance: evidence from China", Review of Quantitative Finance and Accounting, Vol. 55 No. 1, doi: 10.1007/s11156-019-00846-z.

Claessens, S., Djankov, S. and Lang, L.H.P. (2000), "The separation of ownership and control in East Asian corporations", Journal of Financial Economics, Vol. 58 Nos 1/2, doi: 10.1016/s0304-405x(00) 00067-2.

Dahlquist, M. and Robertsson, G. (2001), "Direct foreign ownership, institutional investors, and firm characteristics", Journal of Financial Economics, Vol. 59 No. 3, pp. 413-440, doi: 10.1016/S0304405X(00)00092-1.

David, P. (1996), "Innovation: a test of competing”, Management, Vol. 17 No. 1, pp. 73-84.

Dewenter, K.L. and Warther, V.A. (1998), "Dividends, asymmetric information, and agency conflicts: evidence from a comparison of the dividend policies of Japanese and US Firms", The Journal of Finance, Vol. 53 No. 3, pp. 879-904, doi: 10.1111/0022-1082.00038.

Dyreng, S. and Lindsey, B.P. (2011), "Using financial accounting data to examine the effect of foreign operations located in tax havens and other countries on US multinational firms' tax rates", SSRNElectronic Journal, doi: 10.2139/ssrn.1326602.

Fisman, R.J. and Khanna, T. (2005), "Facilitating development: the role of business groups", SSRN Electronic Journal, February, doi: 10.2139/ssrn.98801.

Friedman, E., Johnson, S. and Mitton, T. (2003), "Propping and tunneling", Journal of Comparative Economics, Vol. 31 No. 4, pp. 732-750, available at: www.francoangeli.it/riviste/Scheda_Riviste. asp?IDArticolo=50182

Gao, L. and Kling, G. (2008), "Equity transfers and market reactions: evidence from Chinese stock markets", Journal of Emerging Market Finance, Vol. 7 No. 3, pp. 293-308, doi: 10.1177/ 097265270800700304.

Gilson, R.J. and Gordon, J.N. (2005), "Controlling controlling shareholders”, SSRN Electronic Journal, p. 228 , doi: $10.2139 /$ ssrn.417181.

Graham, J., Nosek, B.A., Haidt, J., Iyer, R., Koleva, S. and Ditto, P.H. (2011), "Mapping the moral domain", Journal of Personality and Social Psychology, Vol. 101 No. 2, pp. 366-385, doi: 10.1037/ a0021847.

Gugler, K., Mueller, D.C. and Yurtoglu, B.B. (2003), "The impact of corporate governance on investment returns in developed and developing countries", Economic Journal, Vol. 113 No. 491, doi: 10.1046/ j.0013-0133.2003.00167.x.

Gunarsih, T. (2017), "The 36 Th federation of Asean economic associations (faea) conference Asean after the global crisis: Management”, February.

Guo, W., Wang, G., Bao, Y., Li, P., Zhang, M., Gong, Q., Li, R., Gao, Y., Zhao, R. and Shen, S. (2019), "Detection and monitoring of tunneling-induced riverbed deformation using GPS and BeiDou: a case study", Applied Sciences, Vol. 9 No. 13, p. 2759, doi: 10.3390/app9132759.

Hamid, M.A., Ting, I.W.K. and Kweh, Q.L. (2016), "The relationship between corporate governance and expropriation of minority shareholders' interests", Procedia Economics and Finance, Vol. 35 No. 16, pp. 99-106, doi: 10.1016/s2212-5671(16)00014-9.

Hapsoro, D. (2008), "Pengaruh mekanisme corporate governance Terhadap Kinerja Perusahaan", Jurnal Akuntansi Dan Manajemen, STIE YKPN Yogyakarta, Vol. 19 No. 3, pp. 155-172. 
Holmen, M. and Högfeldt, P. (2011), "Pyramidal discounts: tunneling or overinvestment?", SSRN Electronic Journal, doi: 10.2139/ssrn.667743.

Jiang, G. and Lee, C.M.C. (2009), "Institutional knowledge at Singapore management university tunneling through intercorporate loans: the China experience tunneling through inter-corporate loans: the China experience", pp. 1-20.

Jiang, G., Lee, C.M.C. and Yue, H. (2010), "Tunneling through intercorporate loans: the China experience", Journal of Financial Economics, Vol. 98 No. 1, pp. 1-20, doi: 10.1016/j. jifineco.2010.05.002.

Johnson, S., La Porta, R., Lopez-de-Silanes, F. and Shleifer, A. (2000), “Tunneling”, American Economic Review, Vol. 90 No. 2, pp. 22-27.

Juliarto, A., Tower, G., Van der Zahn, M. and Rusmin, R. (2013), "Managerial ownership influencing tunnelling behaviour", Australasian Accounting, Business and Finance Journal, Vol. 7 No. 2, pp. 25-46, doi: 10.14453/aabfj.v7i2.3.

King, L. and Schroeder, H. (2013), "Institutions and environmental change", Institutions and Environmental Change, January, doi: 10.7551/mitpress/9780262240574.001.0001.

Kochhar, R. and David, P. (1996), "Institutional investors and firm innovation: a test of competing hypotheses”, Strategic Management Journal, Vol. 17 No. 1, pp. 73-84, doi: 10.1002/(sici)1097-0266 (199601)17:1<73:.:aid smj795>3.3.co;2-e.

Li, J., Browning, S., Mahal, S.P., Oelschlegel, A.M. and Weissmann, C. (2010), "Darwinian evolution of prions in cell culture”, Science, Vol. 327 No. 5967, pp. 869-872, doi: 10.1126/ science.1183218.

Li, L., Naughton, T. and Hovey, M. (2009), “A review of corporate governance in China”, Codes of Good Governance around the World, pp. 417-438, doi: 10.2139/ssrn.1233070.

Liu, Q. and Lu, Z.J. (2007), "Corporate governance and earnings management in the Chinese listed companies: a tunneling perspective", Journal of Corporate Finance, Vol. 13 No. 5, pp. 881-906, doi: 10.1016/j.jcorpfin.2007.07.003.

Luo, Y. and Jackson, D. (2012a), "Executive compensation, ownership structure and firm performance in Chinese financial corporations", SSRN Electronic Journal, pp. 56-74, doi: 10.2139/ssrn.1893554.

Luo, Y. and Jackson, D.O. (2012b), "CEO compensation, expropriation, and the balance of power among large shareholders", Advances in Financial Economics, Vol. 15, pp. 195-238, doi: 10.1108/S15693732(2012)0000015010.

Marfuah, M. and Azizah, A.P.N. (2014), "Pengaruh Pajak, tunneling incentive dan exchange rate Pada Keputusan transfer pricing perusahaan”, Jurnal Akuntansi and Auditing Indonesia, Vol. 18 No. 2, pp. 156-165, doi: 10.20885/jaai.vol18.iss2.art6.

Ming, J.J. and Wong, T.J. (2005), "Earnings management and tunneling through related party transactions: evidence from Chinese corporate groups”, SSRN Electronic Journal, doi: 10.2139/ ssrn.424888.

Peng, M.W. (2003), "Institutional transitions and strategic choices: implications for corporate social responsibility in Russia Yelena Ruban”, Academy of Management Review, Vol. 28 No. 2, pp. 1-26, doi: 10.5465/AMR.2003.9416341.

Sari, R.C. and Baridwan, Z. (2014), "Current asset tunneling and firm performance in an emerging market”, Jurnal Akuntansi Dan Keuangan Indonesia, Vol. 11 No. 2, pp. 165-176, doi: 10.21002/ jaki.2014.09.

Sari, R.C., Fatimah, P.L.R. and Djajadikerta, H.G. (2016), "Development of tunneling detection model: a new corporate performance improvement”, Jurnal Pengurusan, Vol. 48, pp. 33-46, doi: 10.17576/ pengurusan-2016-48-03.

Shleifer, A. and Vishny, R.W. (1997), "Surveycorpgov", The Journal of Finance, Vol. 52 No. 2, pp. 737-783.

Tunneling in Indonesia

\section{$+2$}


RAMJ

17,1

Susanti, A. and Firmansyah, A. (2020), "Determinants of transfer pricing decisions in Indonesia manufacturing companies", Jurnal Akuntansi, Perpajakan Dan Auditing, Vol. 22 No. 2, pp. 51-56, doi: xx.xxxxx/JAPA/xxxxx.\%0A.

Tang, T.Y.H. (2016), "Privatization, tunneling, and tax avoidance in Chinese SOEs", Asian Review of Accounting, Vol. 24 No. 3, pp. 274-294, doi: 10.1108/ARA-08-2014-0091.

Tihanyi, L., Johnson, R.A., Hoskisson, R.E. and Hitt, M.A. (2003), "Institutional ownership differences and international diversification: the effects of boards of directors and technological opportunity", Academy of Management Journal, Vol. 46 No. 2, pp. 195-211, doi: 10.2307/ 30040614.

Vegt, V.D., Janszen, A. and Moscariello, A. (2012), "Tunnel valleys: current knowledge and future perspectives", Geological Society Special Publication, Vol. 368 No. 1, pp. 75-97, doi: 10.1144/ SP368.13.

Zhang, X., Yang, X., Strange, R. and Zhang, Q. (2017), "Informed trading by foreign institutional investors as a constraint on tunneling: evidence from China", Corporate Governance: An International Review, Vol. 25 No. 4, pp. 222-235, doi: 10.1111/corg.12206.

Zhuang, J., Edwards, D. and Capulong, M.V.A. (2001), "Corporate governance and finance in East Asia: a study of Indonesia, Republic Of Korea, Malaysia, Philippines and Thailand", Asian Development Bank, Vol. 1.

\section{Corresponding author}

Trisninik Ratih Wulandari can be contacted at: trisninikrw@gmail.com

For instructions on how to order reprints of this article, please visit our website: 